\title{
Peran Stakeholder dalam Penanganan Anak Putus Sekolah di Kota Ambon
}

\author{
The Role of Stakeholder in Handling of Dropout Children in Ambon City \\ Yani Talakua \\ Sekolah Tinggi Keguruan dan Ilmu Pendidikan Biak, Papua \\ yanitalakua13@gmail.com
}

\begin{abstract}
Abstrak
Penelitian ini dilakukan di Kota Ambon Kecamatan Sirimau mengunakan fariabel tunggal (X) yaitu peran pemerintah Kota Ambon dalam penangan anak putus sekolah terhadap (a) Anak Putus Sekolah (b) Orang Tua Sebagai Lembaga Yang Mendasar Dalam Masyarakat (c) Pemerintah Dalam Fungsinya Mencerdaskan Kehidupan Bangsa (Dinas Sosial dan Dinas Pendidikan) (d) Masyarakat dan lingkungan (e) Keaktifan lembaga-lembaga Kemasyarakatan dan sosial dalam bidang pendidikan dan penanganan anak putus sekolah. Pemerintah Kota Ambon secara jelas berusaha untuk mengoptimalkan dan meminimalisasi serta menekan angka anak putus sekolah di Kota Ambon, karena pemerintah Kota Ambon turut ambil bagian dalam proses pembinaan serta perencanaan persiapan generasi muda yang lebih berdaya. Pemerintah Kota Ambon juga terus mengupayakan agar tingkat anak putus sekolah dapat ditekan seminimal mungkin dan bila perlu sampai tuntas. Kemudian lembaga-lembaga masyarakat yang lain juga memiliki peran yang sama dalam membantu proses terwujudnya kehidupan masyarakat yang sejahtera dan makmur serta meminimalisasi tingkat angka pengangguran. Satu sektor penting yang secara langsung menyediakan kontribusi paling besar pada peningkat mutu dari sumber daya manusia adalah sektor pendidikan. Pendidikan anak-anak adalah satu integral bagian dari potensi bangsa. Melalui pendidikan, anak-anak menyiapkan seperangkat pengetahuan, kesadaran positif dan kemauan menemukan dan mengelola tujuan untuk mereka sendiri di masa mendatang.
\end{abstract}

Kata Kunci : Anak, Pendidikan, Peran Stakeholder, Putus Sekolah

\begin{abstract}
Abstrack
This study is conducted in Sirimau Sub-district of Ambon City by using the main variable (X) that is the role of Ambon City government in handling school break students; (a) The School Break Students, (b) The Parents as A Basic Foundation in Society (c) The Government in its Function To educate The Life of The nation (Social Department and Education Department) (d) The Society and The Environment (e) The Activity of Social Foundations and Social as General in Educational Sector and Handling the school break students. The government of Ambon City as clearly make some efforts to optimizing and minimalizing and also to compress the rates of school break students in Ambon City. It is because the government has been optimizing the
\end{abstract}


supports on the sector of education which already discussed at the Chapter III and joining in the process of development and also in planning the preparation of youth which more powerful and rich in the case of sufficient human resources. The government of Ambon City also continues to seek the school break students' level can be pressed as less as it can be finished. Then, other social foundations also has the same role. The important sector that is directly provide the biggest contribution on the rise of the quality of Human Resources (HR) is educational sector. The student's education is one integral part from the national emission. Through the education, students are prepared by a set of knowledge in order to have a positive awareness and willing to find out their own dreams at the future. Afterwards, the birth level also become a main problem or a main material of this study in this essay such as How are the roles of Ambon City Government in handling the school break students.

\section{Key Words: Childern, School Break Students, Role of Stakeholder}

\section{A. Latar Belakang}

Anak putus sekolah adalah murid yang tidak dapat menyelesaikan program belajarnya sebelum waktunya selesai atau murid yang tidak tamat menyelesaikan program belajarnya. Upaya yang dilakukan untuk menurunkan angka putus sekolah dalam rangka penuntasan Wajib Belajar (Wajar) sembilan tahun harus memperoleh perhatian yang serius.

Adanya program Wajib Belajar (Wajar) sembilan tahun dari pemerintah juga ternyata belum dapat menuntaskan permasalahan tingginya angka anak putus sekolah. Permasalahan yang banyak dihadapi oleh kebanyakan anak putus sekolah adalah masalah ekonomi yang kurang mampu untuk mendorong seorang anak dapat menikmati bangku sekolah. Kurangnya perhatian pemerintah pun menjadi hal yang sangat fundamental yang mempengaruhi putusnya sekolah anak. Secara umum memang sudah banyak peraturan Undang-Undang Pemerintah dan Negara dalam mengatur serta memudahkan akses pendidikan yang menjadi dasar untuk memperkuat suatu negara atau bangsa.

Kalau dilihat angka anak putus sekolah di Kota Ambon saat ini mencapai 181.452, hal ini sangat memprihatinkan dan patut menjadi perhatian kita. Seperti yang kita ketahui bersama bahwa Kota Ambon terdapat banyak anak yang semestinya pada usianya harus berada di sekolah tetapi justru beraktivitas di tempat-tempat umum seperti di pasar, tempat-tempat perbelanjaan atau di seputaran dalam kota seperti di Jalan Ay Patti, Lapangan Merdeka dan di pasar-pasar tradisional dan pasar modern.

Semestinya hal ini harus lebih diperhatikan oleh para orang tua dimana orang tua punya peran yang sangat mendasar untuk pendidikan anak serta menjadi panutan serta pondasi yang sangat kuat dalam menopang mental serta psikologi anak pada usia dini. Kurangnya perhatian dari orang tua menjadi salah satu faktor yang sangat mempengaruhi 
mengapa seorang anak bisa putus sekolah. Namun dalam hal inipun menjadi perhatian yang khusus bagi pemerintah dalam memberantas kebodohan dan kemiskinan. Harusnya pemerintah mengambil kebijakankebijakan dalam menangani persoalan anak putus sekolah, tapi dapat dilihat meskipun ada beberapa kebijakan serta peraturan dan bahkan Undang-Undang yang mengatur tentang pentingnya pendidikan bagi anak namun realisasinya belum bisa untuk memenuhi kegelisahan masyarakat.

Berdasarkan latar belakang masalah yang telah diuraikan di atas maka dapat di rumuskan masalah dalam penelitian ini, yaitu "Bagaimana peran pemerintah dalam penanganan anak putus sekolah". Mengingat masalah yang dirumuskan di atas terlalu luas maka untuk mengarahkan dan membatasi masalah dalam penelitian ini akan dibatasi pada faktor-faktor penyebab anak putus sekolah seperti faktor ekonomi, dan kurangnya motivasi serta perhatian orang tua.

\section{B. Kerangka Teori}

\section{Pengertian Peran}

Berdasarkan Kamus Besar Bahasa Indonesia, peranan adalah sesuatu yang menjadi bagian atau memegang pimpinan terutama dalam terjadinya suatu hal atau peristiwa. Menurut Soejono Soekanto dalam buku yang berjudul Sosiologi Suatu Pengantar (2012), menjelaskan pengertian peranan merupakan aspek dinamis kedudukan (status). Apabila seseorang melakukan hak dan kewajibannya sesuai dengan kedudukannya, dia menjalankan suatu peranan. Perbedaan antara kedudukan dan peranan adalah untuk kepentingan ilmu pengetahuan. Keduanya tak dapat dipisah-pisahkan karena yang satu tergantung pada yang lain dan sebaliknya. Tak ada peranan tanpa kedudukan atau kedudukan tanpa peranan. Sebagaimana dengan kedudukan, peranan juga mempunyai dua arti. Setiap orang mempunyai macammacam peranan yang berasal dari pola-pola pergaulan hidupnya. Hal itu sekaligus berarti bahwa peranan menentukan apa yang diperbuatnya bagi masyarakat serta kesempatan-kesempatan apa yang diberikan oleh masyarakat kepadanya.

Peranan adalah suatu rangkaian perilaku yang teratur, yang ditimbulkan karena suatu jabatan tertentu. Kepribadian seseorang mungkin juga amat mempengaruhi bagaimana peranan harus dijalankan. Peranan timbul karena seseorang memahami bahwa ia bekerja tidak sendirian, mempunyai lingkungan yang setiap saat diperlukan untuk berinteraksi. Lingkungan itu luas dan beraneka macam, dan masing-masing akan mempunyai lingkungan yang berlainan. Tetapi peranan yang harus dimainkan pada hakekatnya tidak ada perbedaan (Miftah Thoha 2012).

Menurut Mintzberg (dalam Siswanto, 2012 dan Miftah Thoha 2012), ada tiga peran yang dilakukan pemimpin dalam organisasi yaitu:
a. Peran Antar Pribadi (Interpersonal Role),

Dalam peranan antar pribadi, atasan harus bertindak sebagai tokoh, sebagai pemimpin dan sebagai penghubung agar organisasi yang dikelolahnya berjalan dengan lancar. Peranan 
ini oleh Mintzberg dibagi atas tiga peranan yang merupakan perincian lebih lanjut dari peranan antarpribadi ini. Tiga peranan ini dijelaskan sebagai berikut:

a) Peranan sebagai tokoh (Figurehead), yakni suatu peranan yang dilakukan untuk mewakili organisasi yang dipimpinnya didalam setiap kesempatan dan persoalan yang timbul secara formal.

b) Peranan sebagai pemimpin (Leader), dalam peranan ini atasan bertindak sebagai pemimpin. Ia melakukan hubungan interpersonal dengan yang dipimpin, dengan melakukan fungsifungsi pokoknya diantaranya pemimpin, memotifasi, mengembangkan, dan mengendalikan.

c) Peranan sebagai pejabat perantara (Liaison Manager), disini atasan melakukan peranan yang berinteraksi dengan teman sejawat, staf, dan orangorang yang berada diluar organisasinya, untuk mendapatkan informasi.

\section{Definisi anak putus sekolah}

Putus sekolah adalah proses berhentinya siswa secara terpaksa dari suatu lembaga pendidikan tempat dia belajar atau terlantarnya anak dari sebuah lembaga pendidikan formal, yang disebabkan oleh berbagai faktor, salah satunya kondisi ekonomi keluarga yang tidak memadai (Musfiqon, 2007). Padahal anak adalah manusia yang akan meneruskan cita-cita orang tuanya dan sebagai estafet untuk masa yang akan datang" (D Gunarso, Singgih, 2004).
David W. Kaplan, 2004 (dalam Suharto, 2008), bahwa pertumbuhan dan perkembangan yang baik akan menjadi modal bagi kelangsungan anak sebagai generasi penerus yang baik. Sebaliknya ia juga dapat sebagai penghambat kelangsungan generasi penerus bahkan juga dapat sebagai sumber kesusahan dan malapetaka individu, keluarga dan masyarakat.

Demikian kompleksnya faktor penyebab putus sekolah di bumi pertiwi ini. Dalam Negara Kesatuan RI, adanya Undang-Undang Dasar 1945 yang menjamin hak-hak setiap warga negara untuk memperoleh pengajaran yang layak. Dalam hal ini kesempatan untuk memperoleh pendidikan dasar yang layak adalah merupakan hak setiap warga negara, tanpa kecuali. Latar belakang sosial, budaya, ekonomi dan sebagainya bukanlah penghalang bagi anak-anak usia sekolah untuk mengenyam pendidikan. Jadi, tanggung jawab pendidikan bukan hanya tanggung jawab pemerintah semata, tapi tanggung jawab seluruh-seluruh komponen bangsa utamanya para orang tua. Karena orang tualah orang pertamadan utama dalam mendidik anak.

Hal senada diungkapkan oleh Nazili Shaleh Ahmad (2011) bahwa yang dimaksud dengan putus sekolah yaitu "berhentinya belajar seorang murid baik di tengah-tengah tahun ajaran atau pada akhir tahun ajaran karena berbagai alasan tertentu yang mengharuskan atau memaksanya untuk berhenti sekolah".

Hal ini berarti putus sekolah dimaksudkan untuk semua anak yang tidak menyelesaikan 
pendidikan mereka. Berdasarkan konsep putus sekolah tersebut maka, yang dimaksud dengan putus sekolah dalam penelitian ini adalah, terhentinya proses pendidikan anak dalam menyelesaikan pendidikan sekolah dasar.

\section{Undang-Undang Yang Mengatur Tentang Anak}

Pembukaan Undang-Undang Dasar (UUD) 1945 menyatakan bahwa salah satu tujuan Negara Republik Indonesia adalah mencerdaskan kehidupan bangsa. Hal ini berarti, setiap anak Indonesia berhak memperoleh pendidikan yang bermutu sesuai dengan minat dan bakat yang dimilikinya tanpa memandang Status Sosial, Ras, Etnis, Agama, dan Gender. Undang-Undang Nomor 23 Tahun 2002 tentang Perlindungan Anak menegaskan beberapa hal penting sebagai berikut:

a. Pasal 4 mengungkapkan bahwa setiap anak berhak untuk dapat hidup, tumbuh, berkembang, dan berpartisipasi secara wajar sesuai dengan harkat dan martabat kemanusiaan serta mendapat perlindungan dari kekerasan dan diksriminasi.

b. Pasal 9 mengungkapkan dua hal pokok yaitu;

a) Setiap anak berhak memperoleh pendidikan dan pengajaran dalam rangka pengembangan pribadinya dan tingkat kecerdasannya sesuai dengan minat dan bakatnya.

b) Bagi anak yang menyandang cacat juga berhak memperoleh pendidikan luar biasa, sedangkan bagi anak yang memiliki keunggulan juga berhak mendapatkan pendidikan khusus. Undang-undang tersebut memberi makna bahwa, kesempatan yang sama untuk memperoleh pendidikan, merupakan hak yang dilindungi oleh Undang-Undang.

Kesempatan itu diberikan kepada semua anak-anak Indonesia, tanpa melihat latar belakang apapun, termasuk anak yang memiliki kebolehan fisik atau mental. Sabates, et al. (2011) menyatakan bahwa"policies to improve school progression and reduce the numbers of childrendropping out of school are critical if Universal Primary Education (UPE) isto be achieved". Namun demikian, masih terdapat sejumlah anak-anak terutama yang berada di daerah pedesaan tidak bersekolah dan juga mengalami putus sekolah. Hal ini tentu saja merupakan fenomena yang berkaitan dengan sejumlah faktor.

\section{Faktor - Faktor Yang Mempengaruhi Anak Putus Sekolah}

Ada enam faktor penyebab terjadinya putus sekolah khususnya pada jenjang pendidikan dasar yaitu faktor ekonomi, minat untuk bersekolah rendah, perhatian orang tua yang kurang, fasilitas belajar yang kurang mendukung, faktor budaya dan lokasi atau letak sekolah.

a. Faktor Ekonomi

Faktor ekonomi merupakan faktor pertama penyebab anak putus sekolah. Ketidakmampuan keluarga untuk membiayai segala proses yang dibutuhkan selama menempuh pendidikan atau sekolah dalam 
satu jenjang tertentu, walaupun pemerintah telah mencanangkan Program Pendidikan Gratis dua belas tahun, namun belum berimplikasi secara maksimal terhadap penurunan jumlah anak putus sekolah.

\section{b. Faktor Perhatian Orang Tua}

Kurang perhatian orang tua merupakan faktor kedua. Rendahnya perhatian orang tua terhadap anak dapat disebabkan karena kondisi ekonomi keluarga atau rendahnya pendapatan orang tua sehingga perhatian orang tua lebih banyak tercurah pada upaya untuk memenuhi kebutuhan keluarga.

\section{c. Fasilitas Pembelajaran}

Fasilitas pembelajaran yang kurang memadai merupakan faktor ketiga. Fasilitas belajar yang tersedia di sekolah, misalnya perangkat (alat, bahan, dan media) pembelajaran yang kurang memadai, buku pelajaran kurang memadai, dan sebagainya. Kebutuhan dan fasilitas belajaryang dibutuhkan siswa tidak dapat dipenuhi siswa dapat menyebabkan turunnya minat anak yang pada akhirnya menyebabkan putus sekolah.

\section{d. Minat Anak Untuk Sekolah}

Rendahnya minat anak dapat disebabkan oleh perhatian orang tua yang kurang, jarak antara tempat tinggal anak dengan sekolah yang jauh, fasilitas belajar yang kurang, dan pengaruh lingkungan sekitarnya. Minat yang kurang dapat disebabkan oleh pengaruh lingkungan misalnya tingkat pendidikan masyarakat rendah yang diikuti oleh rendahnya kesadaran tentang pentingnya pendidikan. Ketidakmampuan ekonomi keluarga dalam menopang biaya pendidikan yang berdampak terhadap masalah psikologi anak sehingga anak tidak bisa bersosialisasi dengan baik dalam pergaulan dengan teman sekolahnya selain itu adalah peranan lingkungan.

\section{e. Budaya}

Budaya merupakan faktor kelima yang terkait dengan kebiasaan masyarakat di sekitarnya. Rendahnya kesadaran orang tua atau masyarakat akan pentingnya pendidikan. Perilaku masyarakat pedesaan dalam menyekolahkan anaknya lebih banyak dipengaruhi faktor lingkungan. Mereka beranggapan tanpa bersekolah pun anak-anak mereka dapat hidup layak seperti anak lainnya yang bersekolah, oleh karena di desa jumlah anak yang bersekolah lebih banyak dan mereka dapat hidup layak maka kondisi seperti itu dijadikan landasan dalam menentukan masa depan anaknya. Pandangan banyak anak banyak rejeki membuat masyarakat di pedesaan lebih banyak mengarahkan anaknya yang masih usia sekolah diarahkan untuk membantu orang Tua dalam mencari nafkah.

\section{f. Faktor Lokasi Sekolah}

Lokasi atau letak sekolah merupakan faktor ke enam yang mampu menyebabkan anak putus sekolah. Jarak yang jauh dengan akses yang sulit merupakan hal-hal yang harus dipertimbangkan oleh masyarakat untuk bisa menyekolahkan anak-anaknya. Alat transportasi yang kurang serta jarak antara rumah dengan sekolah yang cukup jauh. Selain itu juga dengan akses yang dirasa sulit, keselamatan pun dianggap tidak terjamin. 


\section{Pengertian Perhatian Orang Tua}

Kesadaran masyarakat akan pentingnya pendidikan untuk meningkatkan taraf hidup, kesejahteraan dan martabatnya sangat diperlukan bagi pendidikan anak. Dengan kesadaran seperti ini masyarakat akan mempunyai pandangan bahwa penyelenggaraan pendidikan adalah sematamatauntuk mereka. Tugas sekolah adalah memberikan pencerahan dan penyadaran di tengah-tengah masyarakat bahwa pendidikan sangatlah penting, artinya untuk peningkatan taraf dan martabat hidup mereka.

Salah satu bentuk dari kesadaran orang tua terhadap keberhasilan pendidikan anaknya adalah dengan memberikan perhatian. Sumadi Suryabrata (2006) mengemukakan bahwa terdapat dua definisi mengenai perhatian yang diberikan oleh para ahli psikologi yaitu: perhatian adalah pemusatan tenaga psikis tertuju kepada suatu objek dan perhatian adalah banyak sedikitnya kesadaran yang menyertai sesuatu aktivitas yang dilakukan.

\section{Hubungan Perhatian Orang Tua dengan Putus Sekolah}

Para ahli sosiologi menyatakan bahwa proses sosialisasi pertama dan utama dari proses sosialisasi di dalam kebudayaan masyarakat manusia adalah sosialisasi di lingkungan keluarga. "Lingkungan keluarga merupakan media pertama dan utama yang secara langsung atau tidak langsung berpengaruh terhadap perilaku dalam perkembangan peserta didik".
Di dalam keluarga anak belajar melakukan interaksi sosial yang pertama serta mulai mengenal tentang perilaku-perilaku yang diperankan oleh orang lain di lingkungannya. Dengan kata lain, pengenalan tentang nilainilai budaya masyarakat dimulai dari lingkungan keluarga. Pendidikan merupakan sesuatu yang paling penting bagi pertumbuhan dan perkembangan pribadi anak.

Untuk itu, peran dari keluarga sangat dibutuhkan sebagai salah satu penentu keberhasilan perkembangan dan penyelengaraan pendidikan anak. Menurut Berns (2004) menyatakan "when families are involved, children benefit by having a more positive attitude toward learning, better attendance, ewer placements in special education, better grades, and increased likelihood of graduating from high school and going to work or continuing their education". Dari apa yang dikemukakan oleh oleh Berns tersebut, dapat diketahui pentingnya keterlibatan orang tua pada pedidikan anak. Dengan keterlibatan orang tua, anak akan memiliki sikap yang positif terhadap belajar sehingga memperoleh nilai yang baik dan memungkinkan anak untuk meneruskan ke jenjang pendidikan yang lebih tinggi serta menyelesaikan pendidikannya.

Menurut BPS (2010) penyebab utama anak sampai mengalami putus sekolah adalah karena kurangnya kesadaran orang tua akan pentingnya pendidikan anak, keterbatasan ekonomi/tidak ada biaya, keadaan geografis yang kurang menguntungkan, keterbatasan akses menuju ke sekolah, karena sekolah jauh 
atau minimnya fasilitas pendidikan. Mudjito AK, (2008) menyatakan bahwa masih banyaknya siswa SD mengalami putus sekolah disebabkan oleh beberapa faktor, antara lain:

a. Upaya pemerintah dalam mengatasi rendahnya kemampuan ekonomi termasuk eksploitasi tenaga anak sebagai pekerja anak oleh orang tuanya demi membantu mencari nafkah keluarga.

b. Upaya pemerintah dalam mengatasi rendahnya pemahaman tentang pentingnya pendidikan dan kurangnya dukungan motivasi dari keluarga".

\section{Metode Penelitian}

Jenis penelitian dalam penelitian ini merupakan penelitian kualitatif. Adapun lokasi penelitian yang dipilih adalah Kota Ambon, Propinsi Maluku. Teknik pengumpulan data yang digunakan adalah Instrumen penelitian, Pedoman Wawancara (Interview Guide). Teknik pengumpulan data dalam penelitian ini berupa wawancara, Observasi, Dokumentasi. Metode analisis data dalam penelitian ini menggunakan analisis kualitatif, kemudian dianalisa secara deskritif yang berpedoman pada pedoman wawancara kemudian hasilnya diinterpretasi, dan ditarik kesimpulan dari data yang di peroleh di lapangan.

\section{Pembahasan}

Seperti yang telah dikemukakan peneliti pada bab I (pertama) pada metode penelitian bahwa penelitian ini akan dianalisa secara deskriptif kualitatif. Dalam bab ini juga peneliti akan memaparkan hasil penelitian dan analisa serta membahas sesuai dengan indikator-indikator yang ingin diteliti.

Dalam mengumpulkan data digunakan daftar pertanyaan atau pedoman wawancara yang secara berurutan di mana terdiri dari enam bagian indikator. Masing-masing terdapat lima sampai delapan pertanyaan sebagai pedoman wawancara untuk mendapatkan informasi secara jelas dari informan. Dalam proses wawancara, peneliti menemukan pertanyaan baru yang diperoleh dari jawaban informan saat diwawancarai. Jawabanjawaban yang disampaikan informan kepada peneliti akan menjadi pembahasan masalah yang diteliti sesuai bagian atau indikator penelitian. Adapun indikator yang pertama adalah sebagai berikut:

\section{a. Anak Putus Sekolah}

Fenomena anak putus sekolah di Indonesia bukan hal yang baru lagi, khususnya di Ambon angka anak putus sekolah dari tahun ke tahun kalau dihitung presentasenya secara kuantitatif maka dapat dikatakan mengalami kenaikan yang cuckup signifikan setiap tahunnya. Fakta sosial yang terjadi pada anak-anak ini tak dapat dipungkiri lagi menjadi salah satu fonomena sosial yang ada di tengah-tengah masyarakat Indonesia khusunya Kota Ambon (Provinsi Maluku) yang mempunyai dampak yang dapat dirasakan secara secara umum maupun secara nasional.

Generasi muda yang seharusnya menjadi penerus dan tongkat estafet bagi pembangunan daerah, bangsa dan negara ini. Ternyata masih ada sebagian kelompok 
anak-anak yang tak dapat menikmati waktu belajar dan menuntut ilmunya di sekolah seperti anak-anak lain dengan semestinya. Hal ini sangat memprihatinkan di mana dapat kita lihat bahwa peran orang tua sebagai lembaga sosial yang sangat fundamental tak mampu untuk menjalankan fungsinya dengan baik.

Fungsi lembaga keluarga yang seharusnya lebih mendasar dalam memberikan pemahaman, perhatian, pengawasan serta memberikan bimbingan hak-hak dari seorang anak untuk menuntut ilmu dengan baik tak mampu menjalankan kenyataan sesuai dengan semestinya. Padahal dalam peraturan Perundang-Undangan dimana yang menyatakan bahwa seorang anak mempunyai hak untuk menuntut ilmu sejak berada dalam kandungan sampai menutup mata tak dapat terealisasikan dengan baik. Hal ini juga menjadi salah satu tolak ukur bagi negara dimana dapat kita lihat bahwa negara dalam fungsinya dan perannya tak mampu menjalankan tanggung jawabnya dalam mencerdaskan kehidupan bangsa dengan baik.

Ada berbagai macam faktor yang menjadi dasar mengapa seorang anak sampai berhenti bersekolah atau putus sekolah, beranjak dari latar belakang tersebut penulis akan memaparkan hasil penelitiannya yang di dalamnya akan dibahas beberapa indikatorindikator penting yang telah dijelaskan.

\section{b. Orang Tua Sebagai Lembaga Yang Mendasar Dalam Masyarakat.}

Orang Tua merupakan lembaga yang paling fundamental dalam yang masyarkat yang memberikan pemahaman nilai norma serta moral yang baik kepada seorang anak, merupakan kewajiban orang tua untuk membrikan pendidikan yang baik kepada seorang anak baik itu pendidikan non formal maupun pendidikan formal.

Tumbuhnya seorang anak denga tatanan nilai dan norma yang baik merupakan tanggung jawab orang tua juga, namun jika seorang anak tumbuh denga pemahaman nilai dan norma yang kurang baik maka dapat dikatakan bahwa orang tua telah lalai dan kurang mampu untuk mendidik dengan baik.

Orang Tua mempunyai peran yang paling utama dalam pertumbuhan dan pendidikan seorang anak, setelah itu baru kemudian lingkungan menjadi faktor selanjutnya anak dapat tumbuh dengan baik, kemudian lembaga pendidikan dan yang paling terakhir adalah masyarakat. Pada indikator ini akan dibahas bagaimana peran orang tua dalam menanggapi serta perannya dalam penangan anak putus sekolah dan tanggapanya soal anak putus sekolah.

\section{c. Pemerintah Dalam Fungsinya Mencerdaskan Kehidupan Bangsa (Dinas Sosial dan Dinas Pendidikan).}

Dalam Undang-Undang Dasar Negara Republik Indonesia pada Alinea ke empat tentang mencerdaskan kehidupan bangsa kalau dilihat pada kenyataanya belum mampu terealisasikan dengan baik. Pada kenyataanya 
masih ada para generasi muda yang pada usianya harus mendatkan haknya yaitu pendidikan malah putus sekolah dan bahkan sampai menjadi anak jalanan.

Dilihat dari falsafah dasar Negara Indonesia tercantum dengan jelas pada alinea ke empat tentang bagaimana tugas dan tanggung jawab negara dalam mencerdaskan kehidupan bangsa tak mampu di wujudkan. Telah berbagai cara juga yang dilakukan pihak pemerintah dalam menekan angka anak putus sekolah.

Kalau kita lihat pada kenyataannya Kota Ambon memang mempunyai angka anak putus sekolah yang sangat rendah hal tersebut dapat peneliti buktikan dengan hasil penelitian. Berikut ini akan ditampilkan tabel persentase angka anak putus sekolah di Kota Ambon tiga tahun terakhir ini, untuk lebih jelasnya dapat di lihat di tabel di bawah ini sebagai berikut:

Tabel 1 Sekolah Dasar (SD)

\begin{tabular}{|c|c|c|}
\hline No & Tahun & $\begin{array}{c}\text { Angka anak putus } \\
\text { sekolah }\end{array}$ \\
\hline 1 & 2012 & 29 \\
\hline 2 & 2013 & 13 \\
\hline 3 & 2014 & - \\
\hline & TOTAL & 42 \\
\hline
\end{tabular}

Sumber Data: Hasil Penelitian, 2015

Dari tabel di atas dapat dilihat tingkat anak putus sekolah pada tahun 2012 adalah yang paling besar yaitu sekitar 29 orang, sedangkan pada tahun 2013 mengalami penurunan yaitu 13 orang dan pada tahun 2014 turun dengan sangat drastis hingga mencapai angka 0 .
Berikut ini akan dijelaskan pula tingkatan anak putus sekolah pada taraf sekolah menengah pertama (SMP) dengan jumlah sebagai berikut:

Tabel 2 Sekolah Menengah Pertama (SMP)

\begin{tabular}{|c|c|c|}
\hline No & Tahun & $\begin{array}{c}\text { Angka anak putus } \\
\text { sekolah }\end{array}$ \\
\hline 1 & 2012 & 22 \\
\hline 2 & 2013 & 12 \\
\hline 3 & 2014 & 2 \\
\hline & TOTAL & 36 \\
\hline
\end{tabular}

Sumber Data: Hasil Penelitian, 2015

Dari tabel di atas dapat dilihat angka anak putus sekolah pada sekolah menengah pertama (SMP) dengan persentase angka sebgai berikut yaitu: pada Tahun 2012 angka anak putus sekolah pada taraf sekolah menengah pertama mencapai angka 22 orang, kemudian pada tahun 2013 angka anak putus sekolah pada Tingkatan sekolah menegah pertama mengalami penurunan yaitu 12 orang dan pada Tahun 2014 menurun dengan sangat drastis yaitu mencapai angka 2 orang.

Sedangkan pada tabel berikut ini akan dijelaskan angka anak putus sekolah pada tingkatan sekolah menengah atas (SMA), untuk lebih jelasnya dapat dilihat pada tabel di bawah ini yaitu sebagai berikut: 
Tabel 3 Sekolah Menengah Atas (SMA)

\begin{tabular}{|c|c|c|}
\hline No & Tahun & Angka anak putus sekolah \\
\hline 1 & 2012 & 32 \\
\hline 2 & 2013 & 64 \\
\hline 3 & 2014 & 17 \\
\hline & TOTAL & 113 \\
\hline
\end{tabular}

Sumber Data: Hasil Penelitian, 2015

Dari tabel di atas dapat dilihat dan dibuat perbandingan bahwa angka anak putus sekolah pada tingkatan Sekolah Menengah Atas sangat besar dengan sekolah Dasar dan Sekolah Menengah Pertama maka tingkatan anak putus sekolah yang paling besar adalah pada tingkatan anak Sekolah menengah Atas yaitu pada Jumlahnya mencapai 113 orang, namun kalau dijabarkan masing-masing pertahun maka sebagai berikut: pada tahun 2012 angka anak putus sekolah pada Sekolah Menegah Atas (SMA) adalah yang paling sedang yaitu dengan angka 32 orang sedangkan pada tahun 2013 angka anak putus sekolah pada sekolah menengah yaitu naik dengan sangat drastis yaitu mencapai angka 64 orang dan pada tahun 2014 angka anak putus sekolah pada sekolah menengah atas (SMA) mengalami penurunan yaitu sampai pada angka 17 orang.

Berikut ini tabel yang mempresentasikan tingkatan yang sama dengan sekolah menengah atas yaitu pada tingkatan Sekolah Menengah Kejuruan (SMK) dengan tabel sebagai berikut:
Tabel 4 Sekolah Menengah Kejuruan (SMK)

\begin{tabular}{|c|c|c|}
\hline No & Tahun & Angka anak putus sekolah \\
\hline 1 & 2012 & 27 \\
2 & 2013 & 109 \\
3 & 2014 & 19 \\
& & \\
& & 155 \\
\hline & TOTAL & \\
\hline
\end{tabular}

Sumber Data: Hasil Penelitian, 2015

Berdasarkan tabel di atas Sekolah Menengah Kejuruan (SMK) mempunyai angka tingkatan anak putus sekolah yang sangat tinggi dibandingkan dengan semua sekolah yaitu dengan perhitungan terakhir mencapai angka 155 orang dengan perincian sebagai berikut, pada tahun 2012 angka anak putus sekolah pada Sekolah Menengah Kejuruan (SMK) mencapai angka 27 orang, sedangkan pada tahun 2013 mencapai angka 109 orang dan pada akhir tahun 2014 mencapai angka 19 yang dengan penjumlahan terakhir keseluruhan tahun mencapai jumlah 155 orang.

\section{d. Masyarakat dan lingkungan}

Masyarakat dan lingkungan menjadi salah satu faktor dan alasan bagaimana tumbuh dan berkembangnya seorang anak, peran dari masyarakat dan lingkungan juga tidak dapat dipisahkan dari kehidupan sosial seorang individu, yang mana tugas masyarakat dan lingkungan turut ambil bagian dalam rangka memajukan dan mencerdaskan kehidupan bangsa yaitu dengan memberikan perhatian khusus pada anak yang ada dilingkungan. bahwa masyarakat dan lingkungan secara tidak langsung memainkan perannya dengan 
baik meskipun dengan cara penyampaian nasehat serta informasi menggunakan bahasa lokal yang dapat diartikan sedikit agak kasar, namun dari situlah dapat dilihat bagaiman masyarakat dan lingkungan menunjukan eksistensi kepeduliannya akan tingkat anak putus sekolah pada lingkungannya.

\section{e. Keaktifan lembaga-lembaga Kemasyarakatan dan sosial dalam bidang pendidikan dan penanganan anak putus sekolah.}

Pada dasarnya kalau berbicara soal pendidikan maka hal ini bukanlah tanggung jawab pemerintah saja tetapi merupakan tanggung jawab semua lapisan masyarakat, dimana yang dimulai dari lembaga yang paling kecil seperti keluarga, lingkungan lembaga pendidikan, lembaga sosial dan lembaga-lembaga kemasyarakatan lainnya seperti tempat pengajian Al'quran, teman bermain, panti asuhan sampai pada kelopok belajar anak usia dini.

Lembaga-lembaga ini mempunyai peran yang sama jika kita berbicara soal mencerdaskan kehidupan bangsa, karena hal tersebut bukan hanya merupakan beban dari pemerintah saja akan tetap merupakan tanggung jawab dan beban moral bagi semua elemen masyarakat jika ingin mencapai terwujudnya mencerdaskan kehidupan bangsa. Lembaga-lembaga ini bukan hanya ada pada tatanan masyarakat kota-kota besar saja tapi juga ada pada tatanan kehidupan masyarakat Maluku terkhususnya Kota Ambon, kalau dilihat biasanya pada Kota Ambon lembaga-lembaga yang banyak menampung dan terlantar dapat kita temukan di tempat-tempat sebagai berikut yaitu Rumah singga yang terletak di seputaran Lateri (Latta), kemudian ada Yayasan Ar'rahman yang terletak di Desa Batu Merah (ongkoliong) kemudian panti asuhan Ina Kaka di Desa Passo dan yayasan Ittaqallah yang terletak di kawasan Kebun Cengkeh dan masih banyak lagi yayasan-yayasan serta lembaga-lembaga yang banyak menampung anak-anak yang kurang beruntung ini.

Kemudian dapat dilihat juga kalau sebenarnya lembaga-lembaga sosial ini telah menjalankan salah satu tugas yang sangat mulia dan juga turut ambil bagian dalam memajukan daerah bangsa dan negara terkhususnya individu. Lembaga-lembaga sosial ini yang mana juga telah berperan aktif dalam mencoba memberdayakan sumber daya manusia lewat pelatihan-pelatihan serta pembinaan dalam rangka mencoba memenuhi keinginan dasar negara yang tercantum dalam Undang-Undang Dasar 1945 yaitu mencerdaskan kehidupan bangsa.

Kemudian apresiasi yang sangat baik juga ditunjukan oleh Pemerintah Kota Ambon yang mana turut ambil bagian dan memainkan perannya dalam membantu serta memberikan bantuan-bantuan berupa uang atau sarana dan prasarana lain yang dapat menunjang berkembang majunya sistem belajar serta pengajaran yang baik pada lembaga-lembaga sosial yang ada di Kota Ambon.

\section{E. Kesimpulan}

Berdasarkan hasil penelitian dan wawancara langsung di lapangan serta pemaparan pada 
bab-bab yang sebelumnya yang bertujuan untuk mengetahui bagaimana Peran Pemerintah Kota Ambon dalam penanganan anak putus sekolah.

Jadi kesimpulannya adalah sebagai berikut, yaitu Pemerintah Kota Ambon secara jelas berusaha untuk mengoptimalkan dan meminimalisasi serta menekan angka anak putus sekolah di Kota Ambon, mengapa demikian karena pemerintah Kota Ambon pun mengoptimalkan bantuan-bantuan pada sektor pendidikan dan turut ambil bagian dalam proses pembinaan serta perencanaan persiapan generasi muda yang lebih berdaya dan kaya akan sumber daya manusia yang memadai.

Pemerintah Kota Ambon juga terus mengupayakan agar tingkat anak putus sekolah dapat di tekan sekurang-kurangnya dan bila perlu sampai tuntas. Kemudian lembaga-lembaga masyarakat yang lain juga yang mana punya peran yang sama dalam membantu proses terwujudnya kehidupan masyarakat yang sejahtera dan makmur serta meminimalisasi tingkat angka pengangguran.

Adapun saran yang penulis tulis pada penulisan skripsi ini adalah sebagai berikut:

a. Pemerintah harus lebih mengoptimalkan sistem kerja pada sektor pendidikan sehingga dapat meminimalisasi angka tingkat anak putus sekolah.

b. Pemerintah juga harus dapat mengoptimalkan semua batuan pada sektor pendidikan agar dapat menunjang sitem pembelajaran serta sarana dan prasarana pada lembaga-lembaga pendidikan.

c. Pemerintah juga harus memberikan perhatian khusus pada lembaga-lembaga non formal yang mana mempunyai peran dalam pembinaan karakter serta pembekalan sumber daya manusia pada anak putus sekolah.

d. Pemerintah juga harus bisa merangkul seluruh lembaga-lembaga non formal agar dapat mengoptimalkan sistem pemberdayaan pada anak-anak putus sekolah. Pemerintah harus lebih tegas dan serius dalam penanganan angka anak putus sekolah.

\section{Daftar Pustaka}

Abdul Munir Mulkhan. 2002. Nalar Spiritual Pendidikan, Solusi Problem Filosofis Pendidikan Islam. Yogyakarta: Tiara Wacana.

Adisaputro, Gunawan. 2010. Manajemen Pemasaran Analisis Untuk Perancangan Strategi Pemasaran. Yogyakarta: UPP STIM YKPN

Ahsan, Siswanto, Hani Riska, 2008. Hubungan antara Obesitas dengan Tingkat Perkembangan Anak Usia Prasekolah (4-6 tahun) di TK Plus Al Kautsar Malang, Skripsi, Fakultas Kedokteran, Universitas Brawijaya, Surabaya

Ahmad, Nazili Shaleh. 2011. Pendidikan dan Masyarakat. Yogyakarta: Sabda Media Ali,Muhammad, Strategi Penelitian Pendidikan Statistik Bandung, Bumi Aksara, 1993

Ary H. Gunawan. 2010. Sosiologi pendidikan: Suatu analisis sosiologi 
tentang berbagai problem pendidikan. Jakarta: Rineka Cipta.

Badan Pusat Statistik Kota Ambon StatisticsBps Ambon regional Office Tahun 2012,2013,2014.

BPS. 2010. Statistik Pendidikan 2009. Jakarta: BPS RI

Berns, R.M. 2004. Child, family, school, community, socialization and support. Australia: Thomson.

Berry, David. 2003. Pokok-Pokok Pikiran dalam Sosiologi. Jakarta: PT Rajagrafindo Persada.

D. Gunarsa, Singgih. Yulia singgih D. Gunarsa. 2004. Psikologi Perkembangan Anak dan Remaja. Jakarta: Gunung Mulia.

Lexy J. Moleong. 2002. Metodologi Penelitian Kualitatif. Bandung: PT Remaja.

Miftah Thoha. 2010. Kepemimpinan dan manajemen. Jakarta: Rajawali Pers

Mudjito AK. 2008. Kebijakan direktorat pembinaan TK dan SD. Jakarta: Departemen Pendidikan Nasional Direktorat Jenderal Manajemen Pendidikan Dasar Menengah Direktorat Pembinaan Taman KanakKanak dan Sekolah Dasar.

Musfiqon. 2012. Pengembangan Media dan Sumber Media Pembelajaran. Jakarta: PT. Prestasi Pustakaraya.

Sabates, R., Akyeampong, K., Westbrook, J. \& Hunt, F. 2011. School drop out: Patterns, causes, changes and policies. Diambil dari: unesdoc.unesco.org/images/.../190771 e.pdf. diakses tanggal 15 Januari 2014.Salkind, NJ. (Eds). (2008). Encyclopedia of educational psychology. United States: SAGE Publications, Inc.

Soekanto, Soerjono. Ali Namsa 2007. Sosiologi suatu Pengantar. Jakarta: P.T.Raja Grafindo.

Suharto, Edi 2008. Kebijakan Sosial sebagai Kebijakan Publik. Bandung: Alfabeta.

Sumadi Suryabrata. (2006). Psikologi Pendidikan. Jakarta: PT Raja Grafindo Persada.

Veithzal, Rivai. 2005. Manajemen Sumber Daya Manusia.Jakarta : Raja Grafindo Persada. 
Spirit Publik Volume 13, Nomor 1, April 2018

Halaman 1-16

P-ISSN. 1907-0489 E-ISSN 2580-3875 